
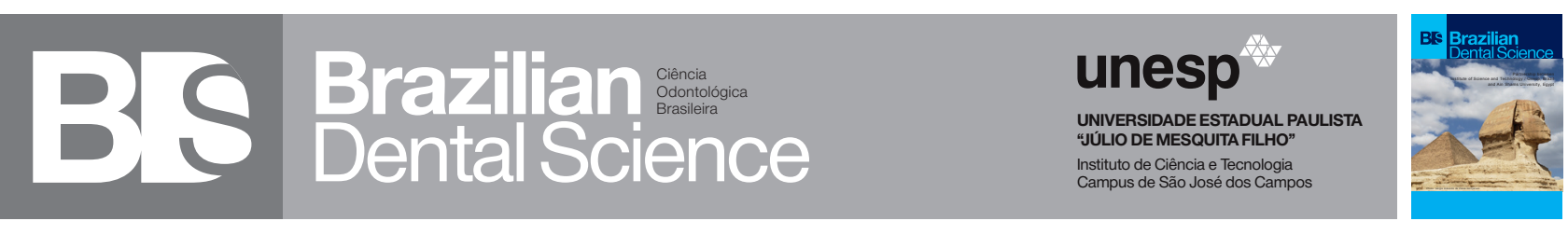

\title{
Correlation Between Dental Caries And Salivary Albumin In Adult Population In Chennai: An In Vivo Study
}

Correlação entre cárie dentária e albumina salivar na população adulta de Chennai: um estudo in vivo

Akshay KHANDELWAL ${ }^{1}$, Ajitha PALANIVELU ${ }^{1}$

1 - Department of Conservative Dentistry and Endodontics - Saveetha Dental College and Hospital - Saveetha University - Chennai - India.

\section{ABSTRACT}

Objective: To evaluate the relationship between dental caries and levels of salivary albumin in unstimulated saliva of adults between the age group of 18 and 40 years from Chennai with varying caries experience as determined by their Decayed Missing Filled Teeth (DMFT) scores. Material and Methods: The study was conducted on 60 healthy adult subjects with age group between 18 and 40 years. The healthy subjects without any chronic diseases, gingival or periodontal problems were selected. The patients were divided into four groups according to DMFT status as Group 1, DMFT 0; Group2, DMFT 1-5; Group 3, DMFT 6-10; and Group 4, as DMFT above 10. Unstimulated saliva samples were collected from each subjects and the salivary albumin levels were estimated using the bromocresol green method (albumin colorimetric test). The obtained data was statistically analysed using one-way ANOVA and Tukey`s Honestly Significant Difference test. Results: The mean salivary albumin levels for the groups 1, 2, 3 and 4 were .086 $\pm .009 \mathrm{mg} /$ $\mathrm{ml}, .083 \pm .006 \mathrm{mg} / \mathrm{ml}, .070 \pm .008 \mathrm{mg} / \mathrm{ml}$ and $.056 \pm .009 \mathrm{mg} / \mathrm{ml}$ respectively. There was an increase in incidence of caries with decrease in salivary albumin level. There was a statistically significant difference among the groups except group 1 and 2 . Conclusion: There is a significant relationship between the salivary albumin level and the incidence of dental caries. An increase in incidence of caries with decrease in salivary albumin levels was seen suggestive of its importance in maintenance of tooth integrity.

\section{KEYWORDS}

Caries; Caries incidence; Dental caries; Salivary albumin; Salivary protein. 228

\section{RESUIMO}

Objetivo: Avaliar a relação entre cárie dentária e níveis de albumina salivar na saliva não-estimulada de adultos entre a faixa etária de 18 e 40 anos da população de Chennai com experiência de cárie variável, conforme determinado pelos escores do índice de dentes cariados, perdidos e obturados (CPOD). Material e Métodos: O estudo foi realizado em 60 indivíduos adultos saudáveis com faixa etária entre 18 e 40 anos. Os indivíduos saudáveis sem doenças crônicas, problemas gengivais ou periodontais foram selecionados. Os pacientes foram divididos em quatro grupos de acordo com o status CPOD como Grupo 1, CPOD 0; Grupo 2, CPOD 1-5; Grupo 3, CPOD 6-10; e Grupo 4, como CPOD acima de 10. Amostras de saliva não estimuladas foram coletadas de cada indivíduo e os níveis de albumina salivar foram estimados usando o método de bromocresol verde (teste colorimétrico da albumina). Os dados obtidos foram analisados estatisticamente usando oneway ANOVA e teste de Tukey. Resultados: Os níveis médios de albumina salivar para os grupos 1, 2, 3 e 4 foram de 0,086 $\pm 0,009 \mathrm{mg} / \mathrm{ml}, 0,083 \pm 0,006$

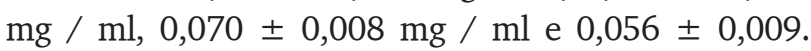
$\mathrm{mg} / \mathrm{ml}$, respectivamente. Houve aumento na incidência de cárie com diminuição do nível de albumina salivar. Houve diferença estatisticamente significante entre

os grupos exceto grupo 1 e 2. Conclusão: Existe uma relação significativa entre o nível de albumina salivar e a incidência de cárie dentária. Um aumento na incidência de cáries com diminuição nos níveis de albumina salivar foi visto como sugestivo de sua importância na manutenção da integridade dentária.

\section{PALAVRAS-CHAVE}

Cárie; Incidência de cáries; Cárie dental; Albumina salivar; Proteína salivar.

Braz Dent Sci 2019 Apr/Jun;22(2) 


\section{INTRODUCTION}

$\mathrm{D}$ ental caries is a multifactorial microbial disease that is caused by the interactions among acidogenic bacteria, fermentable carbohydrates and various host factors including saliva [1]. Saliva contains a variety of molecular and microbial analytics [2-5] which may be effective indicators of both local and systemic disorders [6]. Salivary diagnostics is an interesting topic for research and a lot of investigations are being carried out for identification of salivary biomarkers for disorders ranging from caries to infectious diseases and cancer $[7,8]$.

Salivary proteins like statherin, the acidic PRP's, albumin, histatins and cystatins are multifunctional proteins and are partly responsible in the remineralization capacity of saliva [9]. These proteins are different from the other salivary host defence proteins as they have a specific function in the oral environment i.e. maintenance of homeostasis of supersaturated state of saliva. Association between caries experience and concentrations of lactoferrin, albumin, lysozyme, mucin and cystatin in submandibular or sublingual gland saliva has been reported [10]. However, studies concerning salivary proteins and dental caries have presented conflicting results [11].

Serum albumin levels can act as practical marker of general health and have been used to determine the severity of an underlying pathology [12].Salivary albumin is a serum ultrafiltrate to oral cavity and may diffuse in mucosal secretions. [13] Enamel is protected from demineralization by the inhibitory effects of albumin and other proteins in the protective pellicle, which blocks the pores on its surface [14]. Salivary albumin can be a potential biomarker for caries risk assessment.

Accurate caries risk assessment helps to identify patients with high caries risk for preventive therapies and improved treatment effectiveness [15].Establishing a correlation between salivary albumin and dental caries would be the first step in validation of salivary albumin as a biomarker for caries risk assessment. This study aims to explore the relationship between dental caries and salivary albumin levels.

\section{MATERIAL AND METHODS}

The study was conducted in 60 healthy adult patients coming to the outpatient department of Department of Conservative Dentistry and Endodontics, Saveetha Dental College and Hospitals, Chennai, Tamil Nadu, India with both caries active and caries free subjects under the age group of 18 to 40 years after the approval of Institutional Ethics Committee. The patients included in the study were free from systemic and local diseases which affect salivary secretions, and their caries status was assessed according to WHO criteria [16]. Patients having periodontal disease, hypertension, diabetes, radiotherapy, chemotherapy, systemic disease of the vital organs and history of long-term medications were excluded from the study. The examination of the patients was done by a single examiner to eliminate inter examiner bias. Case history of the subjects was taken in detail. A case history format was filled with an informed consent which was duly signed by the subject.

The occlusal surfaces of the teeth were cleaned with soft bristle brush, dried and examined. Decayed Missing Filled Teeth (DMFT) score was calculated. On the basis of the DMFT scores, the study groups were divided as follows: Control group [Group 1] consists of 15 healthy subjects who were caries free. The caries active groups contains as follows: Group 2 consists of 15 adults with DMFT 1-5, Group 3 consists of 15 subjects of DMFT 6-10, and Group 4 with 15 adults of DMFT above 10. Unstimulated [resting] saliva samples were collected according to Dawes ' method $[17,18]$. Subjects were asked to abstain from smoking, brushing of teeth, use of mouth wash, eat or drink for 1 hour prior to the collection of sample. Samples were collected between 10 and 11 a.m. During sample collection, the subject was seated in the dental chair in upright position. The unstimulated saliva was collected by asking the subjects to pool the saliva in the floor of the mouth and then asked to 
expectorate it into a sterile plastic container. The collected saliva was centrifuged at $3000 \mathrm{rpm}$ for 15 minutes and the supernatant was separated. The sample was then refrigerated at $-10^{\circ} \mathrm{C}$ till the evaluation of albumin level [19].

Salivary albumin was estimated using the Bromocresol green method (albumin colorimetric test) with help of Agappe albumin kit. This kit consists of $5 * 50 \mathrm{ml}$ of reagent. Composition of reagent consists of albumin reagent and albumin standard. The reaction between albumin and dye, bromocresol green produces a change in color that is proportional to the albumin concentration. The samples and reagent were mixed for individual subjects and incubated for a minute. Then the absorbance of standard and samples was measured against a reagent blank. The results obtained were analysed statistically.

Data was entered in Microsoft excel spread sheet and analysed using SPSS software (version 19).Descriptive statistics were used. For significance level, a p value of $<0.05$ was considered statistically significant. The data were statistically analysed with one-way analysis of variance followed by Tukey multiple comparison means to check the difference in salivary albumin level between the groups $(\mathrm{P}<0.01)$.

\section{RESULTS}

A decrease in the mean value of salivary albumin was seen from group 1 to 4 .The mean salivary albumin levels for group 1, 2, 3 and 4 were $0.086 \pm .009,0.083 \pm .006,0.070 \pm .008$ and $0.056 \pm .009 \mathrm{mg} / \mathrm{ml}$ respectively (table 1 ). Group 1, having the highest salivary albumin level followed by group 2, group 3 and group 4 having the least, indicates that there was an increase in the incidence of caries with decrease in the salivary albumin level. Intergroup comparison between the experimental groups using Post hoc analysis by Tukey`s HSD test showed that the decrease in Salivary albumin levels was not significant between Group 1 and 2 ( $\mathrm{P}>0.05$ ), highly significant between all the other groups (P $</=0.001)$.
The comparison between the mean salivary albumin levels for the different groups is demonstrated in table 2 . Statistically significant difference in the salivary albumin levels between the groups indicates a definite correlation between caries index and salivary albumin levels.

Table 1 - Mechanical properties of the materials used in the numerical simulations

\begin{tabular}{|cccc|}
\hline Group & N & $\begin{array}{c}\text { Mean salivary albumin } \\
\text { level }(\mathbf{m g} / \mathbf{m l})\end{array}$ & Std. Deviation \\
\hline 1 & 15 & .0859 & .00936 \\
\hline 2 & 15 & .0829 & .00598 \\
\hline 3 & 15 & .0700 & .00799 \\
\hline 4 & 15 & .0563 & .00904 \\
\hline
\end{tabular}

Table 2 - The intergroup comparison of Salivary Albumin levels between different groups

\begin{tabular}{|c|c|c|c|c|c|c|}
\hline \multirow{2}{*}{$\begin{array}{l}\text { Group } \\
\text { (I) }\end{array}$} & \multirow{2}{*}{$\begin{array}{l}\text { Group } \\
\text { (J) }\end{array}$} & \multirow{2}{*}{$\begin{array}{c}\text { Mean } \\
\text { Difference } \\
(\mathrm{I}-\mathrm{J})\end{array}$} & \multirow{2}{*}{$\begin{array}{l}\text { Std. } \\
\text { Error }\end{array}$} & \multirow{2}{*}{ Sig. } & \multicolumn{2}{|c|}{$\begin{array}{l}\text { 95\% Confidence } \\
\text { Interval }\end{array}$} \\
\hline & & & & & $\begin{array}{l}\text { Lower } \\
\text { Bound }\end{array}$ & $\begin{array}{l}\text { Upper } \\
\text { Bound }\end{array}$ \\
\hline \multirow{3}{*}{1.00} & 2.00 & .00293 & .00299 & .762 & -.0050 & .0109 \\
\hline & 3.00 & $.01587^{\star}$ & .00299 & .000 & .0079 & .0238 \\
\hline & 4.00 & $.02960^{\star}$ & .00299 & .000 & .0217 & .0375 \\
\hline \multirow{3}{*}{2.00} & 1.00 & -.00293 & .00299 & .762 & -.0109 & .0050 \\
\hline & 3.00 & $.01293^{*}$ & .00299 & .000 & .0050 & .0209 \\
\hline & 4.00 & $.02667^{*}$ & .00299 & .000 & .0187 & .0346 \\
\hline \multirow{3}{*}{3.00} & 1.00 & $-.01587^{\star}$ & .00299 & .000 & -.0238 & -.0079 \\
\hline & 2.00 & $-.01293^{*}$ & .00299 & .000 & -.0209 & -.0050 \\
\hline & 4.00 & $.01373^{*}$ & .00299 & .000 & .0058 & .0217 \\
\hline \multirow{3}{*}{4.00} & 1.00 & $-.02960^{*}$ & .00299 & .000 & -.0375 & -.0217 \\
\hline & 2.00 & $-.02667^{\star}$ & .00299 & .000 & -.0346 & -.0187 \\
\hline & 3.00 & $-.01373^{*}$ & .00299 & .000 & -.0217 & -.0058 \\
\hline
\end{tabular}

*. The mean difference is significant at the 0.05 level.

\section{DISCUSSION}

Saliva plays an important role in providing protectionagainstdental caries. Salivahas an excellent buffering action and controls demineralization and mineralization. Its antibacterial activity, cleansing action; and other properties, contribute to the health of teeth [20]. The electrolytes and proteins in saliva control the micro biota and prevent the tooth enamel from dissolving [21]. 
Salivary glycoproteins play an important role in maintaining the structure of microcrystals of hydroxyapatite and fluorapatite, responsible for its remineralising property [22]. Quantitative studies on salivary concentrations of predominant protein components have been rarely conducted. Mandel et al. [23] found no difference in parotid salivary proteins between caries-resistant and caries-active adults. According to Balekjian et al. [24] caries-rampant group exhibited a significant reduction in the proportion of basic proteins and a significant increase in amylase compared to a caries-resistant group. Conversely, Mandel and Bennick [25] found no differences in concentrations of the acidic PRPs between caries free and caries-susceptible subjects. While quantitative studies of salivary composition and caries activity have been inconclusive, there is evidence that similar proteins in saliva from caries-active and caries-free individuals may have different levels of biological activity [26-29]. The present study evaluated the relationship between salivary albumin levels and dental caries.

Salivary albumin is increased in medically compromised patients such as in conditions of immunosuppression, radiotherapy and diabetes [30] and also in patients having gingival and periodontal infection [31,32] for this reason people having such conditions were excluded from the study sample.

According to the results of the present study we found significant relationship between salivary albumin and dental caries in 20-40 year old individuals. There was an increase in the incidence of dental caries with decrease in salivary albumin levels. These results are in accordance with the studies by Mungia et al. [10] wherein they found significant associations between caries and the salivary proteins namely albumin, lactoferrin. lysozyme and mucin [10]. Yoshihara et al. [33] found that there is high possibility of a relationship between root caries and serum albumin concentration. Later Yoshihara et al. [12] conducted a cross sectional study wherein they confirmed that serum albumin concentration correlates with root caries events. They concluded that persons with hypoalbuminemia are at high risk for root caries. These studies support the results of the present study. However, Rafieian Kupaei et al. [34] concluded from their study that there was no significant relationship between albumin and dental caries in 13-19 year old individuals. The variations in the results might be due to the differences in the method of collection of the sample, the selection of the subjects and other parameters involved in the study.

The mean difference in salivary albumin was statistically significant between the groups except group 1 and group 2. This may be because Group 2 had a very low caries index of DMFT score $0-5$, and albumin levels are not the only factor responsible for caries incidence. The other reason can be small sample size of the study. But the significant difference in the mean salivary albumin levels of the control group and group 3 and 4 as well as a significant difference in mean salivary albumin in lower caries index groups and higher caries index group indicates a relationship between salivary albumin levels and incidence of dental caries.

Rui et al. [35] confirmed a strong co-relation between large amounts of phosphopeptides, namely proline rich proteins, histain and statherin and the absence of dental caries which reinforces the importance of these peptides in protection of tooth structure. The proteins in the protective pellicle such as statherin, histatin, cystatin and proline rich are too large to penetrate enamel pores. They remain on the surface bound to hydroxyapatite to aid in controlling crystalline growth of the enamel by allowing ingress of minerals into the enamel for remineralization and by limiting mineral egress. This enhances the stability of the hydroxyapatite in the outer tooth structure [34]. Albumin has a molecular weight comparable to the other proteins found in the protective pellicle. This might be the reason for the decrease in the caries levels in patients with higher albumin levels. Further clinical and laboratory studies including ELISA and PCR are required to establish the exact mechanism of the protective nature of salivary albumin for tooth against dental caries. 
This study has a narrow age group and small sample. To establish the validity of the results similar studies with broader age group and larger sample size is recommended.

\section{CONCLUSION}

The present study concludes that there is a significant relationship between the salivary albumin level and the incidence of dental caries. An increase in incidence of caries with decrease in salivary albumin levels was seen suggestive of its importance in maintenance of tooth integrity. Further clinical and laboratory studies are required to establish the exact mechanism of the protective nature of salivary albumin for tooth against dental caries and to establish its reliability as an effective biomarker for caries risk assessment.

\section{REFERENCES}

1. Selwitz R, Ismail A, Pitts NB. Dental caries. Lancet. 2007 Jan 6;369(9555):51-9.

2. Aas A, Jr, Paster BJ, Stokes LN, Olsen I, Dewhirst FE. Defining the normal bacterial flora of the oral cavity. J Clin Microbiol. 2005 Nov;43(11):5721-32.

3. Bonne N, Wong D. Salivary biomarker development using genomic, proteomic and metabolomic approaches. Genome Med. 2012 Oct 30;4(10):82. doi: 10.1186/gm383. eCollection 2012.

4. Park NJ, Li Y, Yu T, Brinkman BMN, Wong DT. Characterization of RNA in saliva. Clin Chem. 2006 Jun;52(6):988-94. Epub 2006 Apr 6.

5. Hu S, Loo JA, Wong DT. Human saliva proteome analysis. Ann N Y Acad Sci. 2007 Mar;1098:323-9.

6. Burbelo PD, Bayat A, Lebovitz EE, ladarola MJ. New technologies for studying the complexity of oral diseases. Oral Dis. 2012 Mar;18(2):121-6. doi: 10.1111/j.1601-0825.2011.01863.x. Epub 2011 0ct 24.

7. Amado LA, Villar LM, De Paula VS, De Almeida AJ, Gaspar AM. Detection of hepatitis A, B, and C virus-specific antibodies using oral fluid for epidemiological studies. Mem Inst Oswaldo Cruz. 2006 Mar;101(2):149-55.

8. Mager D, Haffajee A, Devlin P, Norris C, Posner M, Goodson J. The salivary microbiota as a diagnostic indicator of oral cancer: a descriptive, non-randomized study of cancer-free and oral squamous cell carcinoma subjects. J TransI Med. 2005 Jul 7;3:27.

9. Carlén A, Börjesson A, Nikdel K, Olsson J. Composition of Pellicles Formed In vivo on tooth surfaces in different parts of the dentition, and In vitro on hydroxyapatite. Caries Res. 1998;32(6):447-55.

10. Mungia R, Cano SM, Johnson DA, Dang H, Brown JP. Interaction of age and specific saliva component output on caries. Aging Clin Exp Res. 2008 Dec;20(6):503-8.
11. Martins C, Buczynski AK, Maia LC, Siqueira WL, Castro GF. Salivary protiens as a biomarker for dental caries-a systematic review. J Dent. 2013 Jan;41(1):2-8. doi: 10.1016/j.jdent.2012.10.015. Epub 2012 Nov 9.

12. Yoshihara A, Takano N, Hirotomi T, Ogawa H, Hanada N, Miyazaki H. Longitudinal relationship between root caries and serum albumin. J Dent Res. 2007 Nov;86(11):1115-9.

13. Meurman JH, Rantonen P, Pajukoski H, Sulkava R. Salivary albumin and other constituents and their relation to oral and general health in the elderly. Oral Surg Oral Med Oral Pathol Oral Radiol Endod. 2002 0ct;94(4):432-8.

14. Van der Linden AH, Booij M, ten Bosch JJ, Arends J. Albumin Interaction with Caries-Like Lesions in Bovine Enamel. Caries Res. 1989;23(6):393-8.

15. Krasse B0. Caries risk. A practical guide for assessment and control. 1985.World Health Organization. Oral Health Survey: Basic Methods. 3 ed. Geneva; 1997.

16. Dawes C. Considerations in the development of diagnostic tests on saliva. Ann N Y Acad Sci. 1993 Sep 20;694:265-9.

17. Dawes $\mathrm{C}$. Factors influencing salivary flow rate and composition. In: Edgar WM, O'Mullane DM. Saliva and Oral Health. 2 ed. London: British Dental Association; 1996. p 27.

18. Staber G, Munz E, Portenhauser R. Experiences with the determination of immunoglobulins $\lg A$, $\lg G$ and $\lg M$ with a turbidimetric method. Trial results from 15 clinical laboratories. Med Lab (Stuttg). 1981;34(5):133-7.

19. Dowd FJ. Saliva and dental caries. Dent Clin North Am. 1999 Oct;:43(4):579-97.

20. Levine M. Susceptibility to Dental Caries and the Salivary Proline-Rich Proteins. Int J Dent. 2011;2011:953412. doi: 10.1155/2011/953412. Epub 2011 Nov 29.

21. Galina P, Andrian S, Topoliceanu C, Tofan N, Nica I, Ghiorghe CA, et al. The Influence of xylitol on some salivary parameters involved in saliva remineralisation capacity. Rev Chimie. 2017;68(7):1607-12.

22. Mandel ID, Zorn M, Ruiz R, Thompson RH Jr, Ellison SA. The proteins and protein-bound carbohydrates of parotid saliva in caries-immune and caries-active adults. Arch Oral Biol. 1965 May-Jun;10(3):471-5.

23. Balekjian AY, Meyer TS, Montague ME, Longton RW. Electrophoretic patterns of parotid fluid from caries-resistant and caries-susceptible individuals. J Dent Res. 1975 Jul-Aug;54(4):850-6.

24. Mandel ID, Bennick A. Quantitation of human salivary acidic prolinerich proteins in oral diseases. J Dent Res. 1983 Sep;62(9):943-5.

25. Cowman RA, Schaefer SJ, Fitzgerald RJ, Rosner D, Shklair IL, Walter $\mathrm{RG}$. Differential utilization of proteins in saliva from caries-active and caries-free subjects as growth substrates by plaque-forming streptococci. J Dent Res. 1979 0ct;58(10):2019-27.

26. Cowman RA, Baron SS, Fitzgerald RJ, Danziger JL, Quintana JA. Growth inhibition of oral streptococci in saliva by anionic proteins from two caries-free individuals. Infect Immun. 1982 Aug;37(2):513-8.

27. Rosan B, Appelbaum B, Golub E, Malamud D, Mandel ID. Enhanced saliva-mediated bacterial aggregation and decreased bacterial adhesion in caries-resistant versus caries-susceptible individuals. Infect Immun. 1982 Dec;38(3):1056-9.

28. Cowman RA, Baron SS, Fitzgerald RJ, Stuchell RE, Mandel ID. Comparative growth responses of oral streptococci on mixed saliva or the separate submandibular and parotid secretions from caries-active and caries-free individuals. J Dent Res. 1983 Sep;62(9):946-51. 
29. Bakianian Vaziri P, Vahedi M, Mortazavi H, Abdollahzadeh Sh, Hajilooi M. Evaluation of Salivary Glucose, IgA and Flow Rate in Diabetic Patients: A Case-Control Study. J Dent (Tehran). 2010 Winter;7(1):13-8. Epub 2010 Mar 31.

30. Henskens YM, van der Velden U, Veerman EC, Nieuw Amerongen AV. Protein, albumin and cystatin concentrations in saliva of healthy subjects and of patients with gingivitis or periodontitis. J Periodontal Res. 1993 Jan;28(1):43-8.

31. Basu MK. Albumin in saliva during experimentally induced gingivitis. $J$ Dent Res. 1984;63:514.
32. Yoshihara A, Hanada N, Miyazaki H. Association between Serum Albumin and Root Caries in Community-dwelling Older Adults. J Dent Res. 2003 Mar;82(3):218-22.

33. Rafieian Kupaei N, Jazaeri M, Rezaei Soufi L, Faradmal J, Abdolsamadi $\mathrm{H}$, Shokri Y. Evaluation of the Relationship between Salivary Albumin Level and Dental Caries. Avicenna J Clin Med. 2013;20(2):101-6.

34. Vitorino R, Lobo MJ, Duarte JR, Ferrer-Correia AJ, Domingues PM, Amado FM. The role of salivary peptides in dental caries. Biomed Chromatogr. 2005 Apr;19(3):214-22.

\section{Ajitha Palanivelu}

(Corresponding address)

Department of Conservative and Endodontics, Saveetha Dental

College, Saveetha University, 162, Poonamallee High Road.

Chennai - 600077, Tamil Nadu, India

Date submitted: 2018 0ct 29

E-Mail: ajitharijesh@gmail.com 